ISSN : 2337-3067

E-Jurnal Ekonomi dan Bisnis Universitas Udayana 7.6 (2018): 1557-1564

\title{
ANALYSIS OF CONSTRUSTION BUDGET FORMULATION : CASE STUDY PUBLIC WORK AGENCY OF TASIKMALAYA REGENCY GOVERNMENT
}

\author{
Bayu Kharisma ${ }^{1}$, Andar Mochamad Zamzam Noor ${ }^{2}$ \\ ${ }^{1}$ Department of Economics, Faculty of Economics and Business, University of Padjadjaran \\ ${ }^{2}$ Public Works and Spatial Administration of Tasikmalaya Regency Government
}

\begin{abstract}
Budget formulation as the first dimensions of budget cycle, has an important role to maintain. A lot of issues will be grow up related to budget priority, objectives, outcomes, and regulation as long as formulation expenditure policy in allocating recources. The study purpose is to explain about the steps in making project cost estimation especially on the stages of budget formulation at the executive budget process. There is a formulation of construstion cost compenent which is regulated by Public Work Minister Rule No.45/PRT/M/2007. Case study of two construction projects budget in Public Work Agency of Tasikmalaya Regency generate some result that the the early estimation cost of proposal in RKA/DIPA is acceptable regarding to its construction cost, but others have to be revised, related to planning cost, supervision cost, and management cost.
\end{abstract}

Keywords : Budget formulation, Project Cost Estimation, Construction Cost Formula

\begin{abstract}
Abstrak
Formulasi anggaran sebagai dimensi pertama dari siklus anggaran, memiliki peran penting untuk dipertahankan. Banyak isu akan tumbuh terkait dengan prioritas anggaran, tujuan, hasil, dan peraturan selama kebijakan pengeluaran formulasi dalam mengalokasikan sumber daya. Tujuan penelitian ini adalah untuk menjelaskan tentang langkah-langkah dalam membuat estimasi biaya proyek terutama pada tahap perumusan anggaran pada proses anggaran eksekutif. Ada rumusan kompensemen biaya construstion yang diatur oleh Peraturan Menteri Pekerjaan Umum No.45 / PRT / M / 2007. Studi kasus dua anggaran proyek konstruksi di Dinas Pekerjaan Umum Kabupaten Tasikmalaya menghasilkan beberapa hasil bahwa perkiraan biaya awal proposal di RKA / DIPA dapat diterima berkenaan dengan biaya konstruksi, namun ada pula yang harus direvisi, terkait dengan biaya perencanaan, pengawasan biaya, dan biaya pengelolaan.
\end{abstract}

Kata kunci: Rumusan anggaran, Estimasi Biaya Proyek, Formula Biaya Konstruksi

1 Corresponding author, email address: ${ }^{1}$ bayu.kharisma@unpad.ac.id 


\section{A. INTRODUCTION}

During budget preparation, trade-offs and prioritization among programs must be made to ensure that the budget fits government policies and priorities. Next, the most costeffective variants must be selected. Finally, means of increasing operational efficiency in government must be sought. None of these can be accomplished unless financial constraints are built into the process from the very start. Accordingly, the budget formulation process has four major dimensions:

- Setting up the fiscal targets and the level of expenditures compatible with targets.

- Formulating expenditure policies.

- Allocating resources in conformity with both policies and fiscal targets. This is the main objective of the core processes of budget preparation.

- Addressing operational efficiency and performance issues.

This paper will be focuses on the process of budget preparation. In particular, the preparation dimensions is at the executive budget process. Study cases will be on a construction project plan in Tasikmalaya local government. Public Work Agency of Tasikmalaya Regency as part of the local Government Institution has the obligation to draw up their annual budget plan. This budget plan will then be discussed by financial agency and approved together with the Local House of Representatives and then set out as a regulation. This budget plan called RKA (Rencana Kerja Anggaran) or Work Plan Budget, in central government, it is usually called DIPA. It has a function of authorization, supervision, planning, distribution, allocation and stabilization.

The proposal of construction project can be a problem because (usually) it is made in a limited time, especially to determine the estimation cost of the project. This situation makes the local Government setting the maximum budget to propose a project. Thus, there is a standard formula to get maximum budget by multiplication between The highest Standard Price of Construction and The Area of Construction. The maximun price of tasikmalaya regency construction project in 2016 is Rp. 3.000.000,00 per m2. 


\section{B. LITERATURE REVIEW}

The general stages of budget cycle can be devided into 4 points of cycle process. First, budget formulation as the terms of executive draft budget. Second, Budget enactment, when Financial Institution presents budget to parliament, which can be an interactive process including debates to get approval. Third, Budget execution by government agencies or department to implementing the programs and spend the funds. Fourth, Budgetting auditing and assesment, where agencies or departement report the expenditure and will be investigated by Auditor. As the first dimension on general stages of budget cycle, budget formulation has some conditions for budget preparation :

1. The need for early decision;

By definition, preparing the budget needs hard choices. These can be made, at a cost, or avoided, at a far greater cost. It is important that the necessary trade-offs be made explicitly when formulating the budget. This will permit a smooth implementation of priority programs, and avoid disrupting program management during budget execution. Political considerations, the avoidance mechanisms mentioned below, and lack of needed information (notably on continuing commitments), often lead to postponing these hard choices until budget execution. The postponement makes the choices harder, not easier, and the consequence is a less efficient budget process.

2. The need for hard constraint

It is because of annual budget preparation must be framed, and should be organized along the following lines:

- A top-down approach, consisting of: (i) defining aggregate resources available for public spending; (ii) establishing sectoral spending limits that fits government priorities; and (iii) making these spending limits known to line ministries;

- A bottom-up approach, consisting of formulating and costing sectoral spending programs within the sectoral spending limits; and

- Iteration and reconciliation mechanisms, to produce a constant overall expenditure program.

3. Avoiding questionable budgeting practices; 
Bayu Kharisma and Andar Mochamad Zamzam Noor. Analysis of Construstion Budget .....

Certain budgetary practices are widespread, the main ones are "incremental budgeting", "open-ended" processes, "excessive bargaining" and "dual budgeting".

There is some importance in the macroeconomic framework and fiscal targets. Thus, the starting point for expenditure programming are: (i) a realistic assesment of budget likely to be available to the government; and (ii) the establishment objectives. Government expenditure should have the capacity to translate policy priorities into the budget, and then to ensure the actual cost with the budget. Overestimating revenues leads to poor budgey formulation and therefore poor budget execution. In building construction project, there is a clause index to devided the budget into 4 sector : construction cost, planning cost, supervision cost, and management cost. This is covered in Rule of Public Work Minister No.45/PRT/M/2007 about Technical guidelines of state building (Permen PU No.45/PRT/M/2007 tentang Pedoman Teknis Pembangunan Gedung Negara) as figured :

\begin{tabular}{|c|c|c|c|c|c|c|c|c|c|c|c|}
\hline $\begin{array}{l}\text { BIAYA KONSTRUKSI FISIK } \\
\text { (JUTA RP) } \\
\text { KOMPONEN } \\
\text { KEGIATAN }\end{array}$ & $\begin{array}{l}\text { s.d. } \\
250\end{array}$ & $\begin{array}{l}250 \\
\text { s.d. } \\
500\end{array}$ & $\begin{array}{r}500 \\
\text { s.d. } \\
1,000\end{array}$ & $\begin{array}{r}1,000 \\
\text { s.d. } \\
2,500\end{array}$ & $\begin{array}{r}2,500 \\
\text { s.d. } \\
5,000\end{array}$ & $\begin{array}{r}5,000 \\
\text { s.d. } \\
10,000\end{array}$ & $\begin{array}{r}10,000 \\
\text { s.d. } \\
25,000\end{array}$ & $\begin{array}{r}25,000 \\
\text { s.d. } \\
50,000\end{array}$ & $\begin{array}{r}50,000 \\
\text { s.d. } \\
100,000\end{array}$ & $\begin{array}{r}100,000 \\
\text { s.d. } \\
250,000\end{array}$ & $\begin{array}{r}250,000 \\
\text { s.d. } \\
500,000\end{array}$ \\
\hline 1 & 2 & 3 & 4 & 5 & 6 & 7 & 8 & 9 & 10 & 11 & 12 \\
\hline $\begin{array}{l}\text { 1. PERENCANAAN } \\
\text { KONSTRUKSI } \\
\text { (dalam \%) }\end{array}$ & 8.23 & $\begin{array}{l}8.23 \\
\text { s.d. } \\
6.83\end{array}$ & $\begin{array}{r}6.83 \\
\text { s.d. } \\
5.63\end{array}$ & $\begin{array}{r}5.63 \\
\text { s.d. } \\
4.65\end{array}$ & $\begin{array}{r}4.65 \\
\text { s.d. } \\
3.90\end{array}$ & $\begin{array}{r}3.90 \\
\text { s.d. } \\
3.28\end{array}$ & $\begin{array}{l}3.28 \\
\text { s.d. } \\
2.82\end{array}$ & $\begin{array}{r}2.82 \\
\text { s.d. } \\
2.44\end{array}$ & $\begin{array}{l}2.44 \\
\text { s.d. } \\
2.16\end{array}$ & $\begin{array}{r}2.16 \\
\text { s.d. } \\
1.94\end{array}$ & $\begin{array}{l}1.94 \\
\text { s.d. } \\
1.80\end{array}$ \\
\hline $\begin{array}{l}\text { 2. } \text { PENGAWASAN } \\
\text { KONSTRUKSI } \\
\text { (dalam \%) }\end{array}$ & 5.35 & $\begin{array}{l}5.35 \\
\text { s.d. } \\
4.62\end{array}$ & $\begin{array}{r}4.62 \\
\text { s.d. } \\
3.90\end{array}$ & $\begin{array}{r}3.90 \\
\text { s.d. } \\
3.27\end{array}$ & $\begin{array}{r}3.27 \\
\text { s.d. } \\
2.73\end{array}$ & $\begin{array}{r}2.73 \\
\text { s.d. } \\
2.27\end{array}$ & $\begin{array}{r}2.27 \\
\text { s.d. } \\
1.92\end{array}$ & $\begin{array}{r}1.92 \\
\text { s.d. } \\
1.65\end{array}$ & $\begin{array}{r}1.65 \\
\text { s.d. } \\
1.43\end{array}$ & $\begin{array}{l}1.43 \\
\text { s.d. } \\
1.26\end{array}$ & $\begin{array}{l}1.26 \\
\text { s.d. } \\
1.18\end{array}$ \\
\hline $\begin{array}{l}\text { 3. PENGELOLAAN } \\
\text { KEGIATAN } \\
\text { (dalam \%) }\end{array}$ & 14.00 & $\begin{array}{r}14.00 \\
\text { s.d. } \\
10.00\end{array}$ & $\begin{array}{r}10.00 \\
\text { s.d. } \\
6.75\end{array}$ & $\begin{array}{r}6.75 \\
\text { s.d. } \\
4.20\end{array}$ & $\begin{array}{r}4.20 \\
\text { s.d. } \\
2.85\end{array}$ & $\begin{array}{r}2.85 \\
\text { s.d. } \\
1.90\end{array}$ & $\begin{array}{l}1.90 \\
\text { s.d. } \\
1.20\end{array}$ & $\begin{array}{r}1.20 \\
\text { s.d. } \\
0.80\end{array}$ & $\begin{array}{r}0.80 \\
\text { s.d. } \\
0.50\end{array}$ & $\begin{array}{r}0.50 \\
\text { s.d. } \\
0.28\end{array}$ & $\begin{array}{r}0.28 \\
\text { s.d. } \\
0.18\end{array}$ \\
\hline
\end{tabular}

Source : Own Calculations

There is some additional clause of Planning and supervision formulation, which is if the planning and supervision will be done by the third party (consultant), so the percentage is as above. But, if it will be done by agency (self management) so, the percentage formula must be multiply by $60 \%$ of the above index. 


\section{RESULT AND DISCUSSION}

Case study (1) is Hall Building Project of Education Agency of Tasikmalaya Regency (Appendix 1: RKA ) which is continued work from last year project of 1,5 billion rupiah for the Area of building in about $900 \mathrm{~m} 2$ (2 floors). The Detail Engineering Design (DED) is made in 2015 with self management procedure.

Total budget : Rp. 1.000.000.000,00, devided into :

- Construction cost : Rp. 906.940.000,00 (e-procurement)

- Planning cost : Rp. 40.000.000,00 (self management/swakelola)

- Supervision cost : Rp. 35.000.000,00 (self management/swakelola)

- Management cost : Rp. 18.060.000,00 (self management/swakelola)

Analysis of Budget :

As an "incremental budgeting", it should be insignificant problem in the budget formulation. In order to get an early (maximum) estimation cost, the formulation is :

Total Budget estimation = Building project area $\mathrm{x}$ max. price per $\mathrm{m} 2$

$$
=900 \mathrm{~m} 2 \times \text { Rp. } 3 \cdot 000.000,00
$$$$
=\text { Rp. } 2 \cdot 700 \cdot 000 \cdot 000,00
$$

Thus, if all the cost is combined between last year project and the upcoming project, The existing budget will be Rp. 2.500.000.000,00, and it is acceptable in compared to the early estimation formula which is Rp. 2.700.000.000,00.

Based on formulation of Public Work Minister 45/2007, we can assume the fixed calculation cost or maximum value that must be allocate for planning, supervision, and management as follows :

Maximum Planning cost $\quad: 5,63 \%$ x Rp. $1.000 .000 .000,-$ x $60 \%=$ Rp. $33.700 .000,00$

Maximum Supervision cost $: 3,90 \%$ x Rp. $1.000 .000 .000,-$ x $60 \%=$ Rp. $23.400 .000,00$

Maximum Management cost : $10 \%$ x Rp. $1000.000 .000,-$ x 60\% = rp.60.000.000,00 
Case study (2) is Islamic Centre Building Project (Appendix 2: RKA ) which Area of building is about $5200 \mathrm{~m} 2$ (2 floors) and $2700 \mathrm{~m} 2$ of supported buildind. The Detail Engineering Design (DED) is made in 2007 by consultant.

Total budget : Rp. 21.000.000.000,00, devided into :

- Construction cost

- Planning cost

- Supervision cost

- Management cost
: Rp. 20.132.000.000,00 (e-procurement)

: Rp. 450.000.000,00 (self management/swakelola)

: Rp. 400.000.000,00 (self management/swakelola)

: Rp.18.000.000,00 (self management/swakelola)

\section{Analysis of Budget :}

As an "top-down" approach, it can be a problem in the budget formulation. Because, in fact, there is an existing building of Islamic Centre (in the same building, same location), whish is in a feasible condition. The mayor of Tasikmalaya Regency want to change the roof of the building from pyramid into a dome. It will be hard to avoiding questionable budgeting practices in compared to the priority of development in Tasikmalaya regency who still lack of fund to build some agencies building to move to regency region that still operate in the region of Tasikmalaya Municipality.

In order to get an early (maximum) estimation cost, the formulation is :

Total Budget estimation $=$ Building project area $\mathrm{x}$ max. price per $\mathrm{m} 2$

$$
=(5200+2700) \mathrm{m} 2 \times \mathrm{Rp} .3 .000 .000,00
$$$$
=\text { Rp. } 23.700 .000 .000,00
$$

However, the budget of 21 billion rupiah is still below of the maximum cost that can be allocate to the project which is about Rp. 23.700.000.000,00.

Based on formulation of Public Work Minister 45/2007, we can assume the fixed calculation cost or maximum value that must be allocate for planning, supervision, and management as follows (as same formulation as case $<1>$ with interpolation) :

Maximum Planning cost

Maximum Supervision cost

Maximum Management cost
: Rp. 357.000.000,00

: Rp. 245.000.000,00

: Rp. 280.000.000,00

\section{CONCLUSION \& RECOMMENDATION}


In general, the the projects can be implemented by its cost as showed in the budget document. Related to the results of the analysis conducted in this study, it can be summarized that the 2 (two) RKA of construction project budgeting as follows:

1. Based on the two project, both of estimation cost for the early proposal, the total budget is acceptable regarding to the formulation of maximum cost of construction project.

2. Planning cost, supervision cost and management cost must be revised, as regulated in Rule of Public Work Minister No.45/PRT/M/2007.

Furthermore, some recommendation is needed to improve the quality of budgeting preparation in related to its priority tobe relevant, whether the decision has been taken, for instance :

- Budget priority for infrastructure is relevant, but the allocation progress should be maintain of which infrastructure to be done first. As example of Islamic Centre project, nowadays, sort of religious building project can attract a lot of funding from investor, it can be from CSR, foreign block grant (for example: Many Foundation from Middle East Countries). Thus, the budget can be spent to other important allocation.

- Because of the percentage of planning and supervision cost follow the value of construction cost, so, the values of them can be huge related to the formula of Public Work Minister Rule, so, the implementation should be careful and be aware of "rent seeking" in order to minimized the budget leaks from planning cost and supervision cost.

\section{REFERENCES}

Dorotinsky (2017). The Budget Preparation Process. www.worldbank.org http://www1.worldbank.org/publicsector/LearningProgram/PEAM/DorotinskyBackCh4.pdf Accesed on April 022017

Dinas Pekerjaan Umum Penataan Ruang Kabupaten Tasikmalaya (2017). Rencana Kerja Anggaran (RKA) Perubahan SKPD.

Lee, Robert D, (2013). Public Budgeting Systems Ninth-Edition. Jones \& Bartlett Learning. 2013. ISBN 978-1-4496-2790-4 
Bayu Kharisma and Andar Mochamad Zamzam Noor. Analysis of Construstion Budget .....

Peraturan Menteri Pekerjaan Umum Nomor 45/PRT/M/2007 tentang Pedoman teknis Pembangunan Gedung Negara 